\title{
DAMPAK DEPRESIASI NILAI TUKAR DAN PERTUMBUHAN UANG BEREDAR TERHADAP INFLASI: APLIKASI THRESHOLD MODEL ${ }^{1}$
}

\author{
Rizki E. Wimanda ${ }^{2}$
}

\begin{abstract}
This paper investigates the impact of exchange rate depreciation and money growth to the CPI inflation in Indonesia. Using monthly data from 1980:1 to 2008:12, our econometric evidence shows that there are indeed threshold effects of money growth on inflation, but nothreshold effect of exchange rate depreciation on inflation. Even though the threshold value for exchange rate depreciation is found at $8.4 \%$, the F-test suggests that there is no significant difference between the coefficient below and that above the threshold value. While, two threshold values are found for money growth, i.e. $7.1 \%$ and $9.8 \%$, and they are statistically different. The impact on inflation is high when money grows by up to $7.1 \%$, it is moderate when money grows by $7.1 \%$ to $9.8 \%$, and it is low when money grows by above $9.8 \%$.
\end{abstract}

JEL Classification: C22; E31; E51.

Keywords: Inflation, Threshold Effect; Indonesia

1 Disarikan dari Wimanda (2010), Doctoral Thesis, Bab 4, yaitu "Threshold Effects of Exchange Rate and Money Growth on Inflation".

2 Peneliti Ekonomi di Bank Indonesia, email: rizki@bi.go.id. 


\section{PENDAHULUAN}

Perhatian terhadap inflasi begitu besar sejak Indonesia mengadopsi inflation targeting pada tahun 2000. Salah satu topik studi yang penting adalah meneliti faktor-faktor penyebab inflasi.

Wimanda (2010) ${ }^{3}$ menemukan bahwa inflasi di Indonesia dipengaruhi secara signifikan oleh ekspektasi inflasi (backward-looking dan forward-looking), output gap, depresiasi nilai tukar, dan pertumbuhan uang beredar. Analisis terhadap sample bulanan mulai dari awal tahun 1980 sampai dengan akhir tahun 2008 menunjukkan bahwa pembentukan ekspektasi inflasi di Indonesia masih didominasi oleh ekspektasi inflasi ke belakang (backward-looking) dengan porsi sekitar 0.7, sementara porsi ekspektasi inflasi ke depan (forward-looking) sekitar 0.2. Dalam analisisnya dia juga menemukan bahwa dampak nilai tukar lebih besar dibandingkan dengan dampak pertumbuhan uang beredar (M1). Analisis tersebut mengasumsikan bahwa dampak kedua variable tersebut adalah linear, dalam arti dampaknya adalah konstan untuk setiap tingkat depresiasi nilai tukar dan pertumbuhan uang beredar.

Dengan menggunakan threshold model paper ini menguji apakah dampak nilai tukar dan pertumbuhan uang beredar terhadap inflasi linear atau tidak. Selanjutnya, akan diuji apakah terdapat nilai threshold, berapa banyak nilai threshold yang dapat diidentifikasi, dan berapa berapa besar dampaknya.

Adapun sistematika penulisannya adalah sebagai berikut. Studi literatur akan dibahas pada bagian kedua. Metodologi dan data akan dibahas pada bagian ketiga dari paper ini. Sementara hasil estimasi dan kesimpulan akan dipaparkan pada bagian keempat dan kelima.

\section{TEORI}

\subsection{Pass-through Nilai Tukar}

Salah satu isu sentral di ekonomi internasional adalah pass-through nilai tukar dimana didefinisikan sebagai dampak dari 1 persen depresiasi nilai tukar pada inflasi domestik. Secara umum, untuk menguji pass-through nilai tukar adalah dengan mengetimasi pada persamaan berikut:

$$
\pi_{t}=\alpha+\gamma e_{t}+\delta x_{t}+\varepsilon_{t}
$$

dimana $\pi_{t}$ adalah inflasi domestik, $e_{t}$ adalah depresiasi nilai tukar (nominal), dan adalah variabelvariabel control lainnya (dalam bentuk pertumbuhan).

3 Pada Bab 3 Doctoral Thesis, yaitu "Determinants of Inflation and The Shape of Phillips Curve". 
Secara umum, studi mengenai pass-through nilai tukar ini dapat dikelompokkan menjadi 3. Kelompok pertama adalah studi dampak nilai tukar pada harga impor industri tertentu, misalnya Bernhofen and Xu (1999) and Goldberg (1995). Kelompok kedua adalah studi dampak nilai tukar pada harga import secara aggregat, misalnya Hooper dan Mann (1989) dan Campa dan Goldberg (2005). Dan kelompok ketiga adalah studi dampak nilai tukar pada CPI atau WPI, misalnya Papell (1994) dan McCarthy (2000).

Meskipun literatur pada pass-through nilai tukar ini sangat banyak, namun studi empiris yang ada lebih banyak fokus pada negara-negara maju. Sebuah survey yang dilakukan oleh Menon (1995) menunjukkan bahwa dari 48 studi mengenai pass-through nilai tukar sebagian besar adalah Amerika dan Jepang. Begitu pula dengan Goldberg dan Knetter (1997) yang menyatakan bahwa studi pass-through nilai tukar selama tahun 1980-an didominasi oleh Amerika.

Untuk negara-negara yang bergabung dalam OECD, studi dampak pass-through nilai tukar pada harga impor dilakukan oleh Campa dan Goldberg (2005). Mereka menemukan bahwa pass-through nilai tukar adalah parsial, dimana harga impor mencerminkan 60 persen pergerakan nilai tukar dalam jangka pendek dan hampir 80 persen dalam jangka panjang. Mereka juga menemukan bahwa negara-negara yang memiliki volatilitas nilai tukar yang rendah dan inflasi yang rendah memiliki dampak pass-through nilai tukar yang rendah.

Menggunakan data 71 negara dari tahun 1979 sampai dengan 2000, Choudhri dan Hakura (2006) memperlihatkan bahwa ada hubungan positif yang kuat antara pass-through nilai tukar dengan rata-rata inflasi. Negara-negara yang memiliki inflasi yang rendah cenderung memiliki pass-through nilai tukar yang rendah. Begitu pula sebaliknya.

Hubungan nilai tukar dan inflasi di Malaysia, Philipines, dan Singapore diteliti oleh Alba dan Papper (1998) selama periode 1979:Q1 sampai dengan 1995:Q2. Mereka menemukan bahwa pass-through nilai tukar untuk Philipina lebih tinggi dibandingkan Malaysia, sementara pass-through nilai tukar untuk Singapore justru bernilai negatif.

Untuk mensupport argumen "fear of floating", Calvo dan Reinhart (2000) meneliti hal yang sama untuk sejumlah negara maju dan berkembang, termasuk Malaysia dan Indonesia. Dengan menggunakan data bulanan dari Agustus 1997 sampai November 1999, mereka menemukan pass-through nilai tukar di Indonesia adalah 0.062 .

\subsection{Hubungan antara Uang dan Inflasi}

Teori kuantitas dan persamaan pertukaran memberikan kerangka yang berguna untuk menganalisa secara empiris relevansi uang di dalam perekonomian. Hubungan uang dan inflasi dapat diturunkan dari persamaan permintaan uang. Masyarakat ingin memegang uang untuk 
membeli barang dan jasa. Jika harga barang dan jasa naik, masyarakat cenderung akan memegang uang lebih banyak. Faktor yang paling penting dalam permintaan uang adalah pendapatan. Pada saat pendapatan masyarakat naik, masyarakat akan cenderung untuk berbelanja lebih. Pengeluaran yang lebih banyak berhubungan dengan memegang uang yang lebih banyak. Dengan demikian, hubungan ini dapat ditulis sebagai:

$$
\frac{M}{P}=k Y \text {, }
$$

dimana $M$ adalah uang nominal, $P$ adalah tingkat harga berdasarkan CPI atau deflator PDB, $Y$ adalah pendapatan dan $k$ merupakan faktor proporsi. Persamaan (2) dapat ditulis ulang menjadi:

$$
P=\frac{1}{k} \frac{M}{Y}
$$

Dengan mengasumsikan adanya kausalitas dari $M$ ke $P$, persamaan (3) menyebutkan bahwa kuantitas uang menentukan level harga, namun uang bukan merupakan satu-satunya faktor. Misalnya, pendapatan dan faktor lainnya yang terrefleksi dalam k tidak berubah, pada saat kuantitas uang meningkat, maka level harga akan meningkat.

Milton Friedman (1968) berargumen bahwa inflasi merupakan fenomena moneter. Studistudi yang dilakukan oleh Lucas (1980), Dwyer dan Hafer (1988), Friedman (1992), Barro (1993), McCandless dan Weber (1995), Dewald (1998), Rolnick dan Weber (1997) dan lainnya berkesimpulan bahwa perubahan kuantitas uang dan perubahan harga mempunyai hubungan yang erat.

Dwyer dan Hafer (1999) memperlihatkan level harga mempunyai hubungan yang positif dan proporsional dengan kuantitas uang di Amerika, Inggris, Jepang, Brazil, dan Chile selama abad 20. Mereka juga menunjukkan bahwa dalam jangka waktu yang lebih pendek, yaitu 5 tahun, hubungan pertumbuhan uang dan inflasi tetap berlaku.

Studi empiris hubungan antara pertumbuhan uang (M1 dan M2) dan inflasi pada 160 negara dilakukan oleh De Grauwe dan Polan (2005). Mereka menunjukkan bahwa selama kurun waktu 30 tahun, hubungan pertumbuhan uang beredar dan inflasi masih berlaku. Namun demikian, setelah membagi sampel berdasarkan tingkat inflasi, mereka menunjukkan bahwa negara-negara yang memiliki inflasi yang rendah (di bawah 10\%) hubungan kedua variabel tersebut melemah. Sebaliknya, hubungan tersebut kuat untuk negara-negara yang tingkat inflasinya tinggi. Namun demikian, studi ini tidak menentukan pada level berapa uang beredar akan memberikan dampak yang berbeda pada inflasi. 


\subsection{Aplikasi Threshold Model}

Threshold mode/ merupakan kasus spesial dari kerangka statistik yang kompleks, seperti mixture model, switching model, Markov-switching model, dan smooth transition threshold model (Hansen, 1997).

Threhold model dapat diaplikasikan pada banyak kasus. Misalnya, Galbraith (1996) melakukan studi mengenai hubungan antara uang dan output. Dengan menggunakan data Amerika dan Canada, dia menemukan bahwa uang memiliki pengaruh yang kuat pada output pada saat pertumbuhan uang di bawah nilai theshold tertentu. Hasil ini konsisten dengan proposisi bahwa kebijakan moneter mempunyai dampak yang kecil atau bahkan tidak memiliki dampak sama sekali pada saat pertumbuhan uang sangat tinggi.

Khan dan Senhadji (2001) meneliti hubungan antara inflasi dan pertumbuhan ekonomi pada 140 negara selama periode 1960 sampai dengan 1998. Mereka berargumentasi bahwa inflasi memiliki dampak yang negatif terhadap perekonomian manakala inflasi di atas nilai threshold tertentu. Sebaliknya, inflasi memberikan dampak yang positif bagi perekonomian manakala inflasi di bawah nilai thresholdnya. Mereka menemukan bahwa nilai threshold untuk negara maju adalah 1-3 persen, sementara untuk negara berkembang nilai threholdnya adalah 11-12 persen.

Threshold model juga digunakan Papageorgiou (2002) dalam mengevaluasi tingkat keterbukaan terhadap perekonomian. Foster (2006) menguji hubungan ekspor dan pertumbuhan ekonomi untuk negara-negara Afrika. Evaluasi terhadap defisit fiskal juga dilakukan dengan menggunakan threhold model, misalnya untuk kasus Amerika (lihat Arestis, Cipollini dan Fattouh, 2004) dan untuk kasus Spanyol (lihat Bajo-Rubio, Diaz-Roldan and Esteve, 2004).

Sementara itu, studi mengenai threshold nilai tukar ke inflasi dan threhold uang beredar ke inflasi, sepanjang pengetahuan kami, belum ada. Untuk itu, studi ini dilakukan dengan maksud mengisi gap literatur.

\section{METODOLOGI}

\subsection{Model Empiris dan Teknik Pengolahan Data}

Studi ini menggunakan threshold mode/ untuk menjawab pertanyaan di atas. Threshold mode/merupakan sebuah kasus spesial dari kerangka statistika yang kompleks, seperti mixture models, switching models, Markov-switching models, dan smooth transition threshold models. Secara umum, threshold model dapat ditulis seperti berikut: 


$$
y_{t}=\beta^{r}{ }_{j} x_{t}+\delta_{l} z_{t} I\left(t h_{t} \leq \lambda\right)+\delta_{2} z_{t} I\left(t h_{t}>\lambda\right)+\mu_{t}
$$

dimana adalah dependent variable, adalah explanatory variable yang ingin diuji, adalah vektor dari explanatory variable yang lain, adalah fungsi indikator, adalah variabel threshold, dan adalah nilai dari threshold. Pada persamaan di atas, observasi dibagi menjadi dua regime tergantung pada apakah variable threshold lebih kecil atau lebih besar dari nilai.

Untuk mengestimasi model, nilai threshold dan nilai parameter slope diestimasi secara bersamaan. Hansen (1997) merekomendasikan untuk mencari estimasi dengan mencari nilai dari sum of squared errors yang minimal. Untuk meyakinkan bahwa jumlah observasi di tiap regime adalah cukup, maka model diestimasi untuk semua nilai threshold dari variabel threshold antara $10^{\text {th }}$ dan $90^{\text {th }}$ percentile.

Setelah ditemukan nilai threshold, kita perlu menguji apakah nilai tersebut signifikan secara statistik atau tidak. Dalam hal ini, apakah hipotesa nol dari ditolak atau diterima. Satu hal yang menjadi komplikasi adalah nilai threshold tidak terindentifikasi pada hipotesa nol. Hal ini berimplikasi bahwa classical test tidak memiliki distribusi yang standar, sehingga nilai-nilai kritis tidak dapat diperoleh dari tabel distribusi standar.

Studi ini mengikuti Hansen $(1997,2000)$ dalam pencarian multiple regimes pada data dengan menggunakan depresiasi nilai tukar dan pertumbuhan M1 sebagai threshold variable. Metode yang berdasarkan asymptotic distribution ini dapat menguji signifikansi dari regime yang terpilih oleh data.

Dalam studi ini, kami tidak mengevaluasi hubungan jangka panjang dari nilai nilai tukar dan uang beredar kepada tingkat harga, namun kami lebih tertarik untuk melihat hubungan jangka pendek dari depresiasi nilai tukar dan pertumbuhan uang beredar terhadap inflasi.

Untuk menguji keberadaan threshold effect dari depresiasi nilai tukar pada inflasi, model hybrid NKPC Phillips curve ini akan diestimasi adalah sebagai berikut:

$$
\begin{aligned}
\pi_{t}= & c+\alpha_{1} \pi_{t-1}+\alpha_{2} \pi_{t+1}^{e}+\beta g a p_{t}+\gamma_{1}\left(1-d_{t}\right)\left[\left(e r_{t}\right) I\left(e r_{t}>e r^{*}\right)\right]+ \\
& \gamma_{2} d_{t}\left[\left(e r_{t}\right) I\left(e r_{t} \leq e r^{*}\right)\right]+\theta m_{t}+\delta_{1} \text { crisis }+\delta_{2} \text { fuel }+\delta_{3} \text { fitri }+\varepsilon_{t}
\end{aligned}
$$

dimana $\quad d_{t}=\left\{\begin{array}{ll}1 & \text { if } e r_{t} \leq e r^{*} \\ 0 & \text { if } e r_{t}>e r^{*}\end{array} \quad, \pi_{t}\right.$ adalah inflasi, $\pi_{t-1}$ adalah ekspektasi inflasi backward-

looking, adalah $\pi_{t+1}^{e}$ ekspetasi inflasi forward-looking, gap adalah output gap, $\mathrm{r}_{t}$ adalah 
depresiasi nilai tukar ${ }^{4}, e r^{*}$ adalah nilai threshold dari nilai tukar, $m_{t}$ adalah pertumbuhan uang beredar (M1), crisis adalah dummy variable untuk menangkap krisis finansial tahun 19971998, fuel adalah dummy variable untuk menangkap kenaikan harga BBM pada bulan Januari 2005 dan Oktober 2005, dan fitri adalah dummy variable untuk menangkap fenomena hari raya Idul Fitri.

Kami menggunakan Instrumental variables (IV) estimators, yaitu two stage least squares (TSLS). Metode estimasi ini dapat mengatasi endogeneity problems mengingat model yang digunakan terdapat nilai inflasi di masa datang.

Estimasi model dilakukan dengan metode conditional least squares yang dapat dijelaskan sebagai berikut: Untuk setiap nilai threshold $e r_{t}^{*}$, model diestimasi melalui TSLS, kemudian diperoleh sum of squared residuals (SSR). Estimasi least squares dari $\mathrm{er}_{t}{ }^{*}$ diperoleh dengan memilih nilai threshold $e r_{t}^{*}$ dimana yang memiliki nilai SSR yang minimum. Jika kita menempatkan seluruh observasi nilai threshold ke dalam vector, maka notasi kompak dari persamaan (2) adalah sebagai berikut:

$$
y=x \beta_{e r}+\varepsilon, e r=\underline{e r}, \ldots . . \overline{e r}
$$

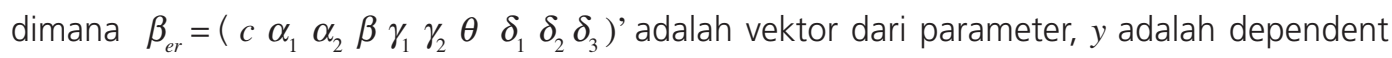
variable, dan $x$ adalah matrix dari explanatory variables. Patut dicatat bahwa koefisien vector $\beta$ di-index-kan dengan er untuk memperlihatkan ketergantungannya pada nilai threshold, dimana berkisar dari $\underline{e r}$ sampai $\overline{e r}$. Kita definisikan $S_{1}(e r)$ sebagai SSR dengan nilai threshold depresiasi nilai tukar pada er. Nilai estimasi $e r^{*}$ threshold yang diperoleh adalah nilai threshold yang mempunyai nilai yang minimal, yaitu:

$$
e r^{*}=\operatorname{argmin}\left[S_{1}(e r), e r=\underline{e r}, \ldots . ., \overline{e r}\right]
$$

Setelah nilai threshold diperoleh, kita perlu menguji apakah threshold effect-nya signifikan secara statistic atau tidak. Pada persamaan (2), untuk menguji apakah threshold effectnya ada atau tidak kita perlu menguji hipotesa nol, yaitu $H_{0}: \gamma_{1}=\gamma_{2}$. Hansen $(1997,2000)$ menyarankan metode bootstrap untuk mensimulasikan asymptotic distribution dari likelihood ratio test dari $H_{0}$ sebagai berikut:

4 Nilai tukar didefinisikan sebagai mata uang domestic per mata uang asing. Dalam hal ini digunakan Rp/USD. Dengan demikian, nilai er yang negatif berarti depresiasi, sementara nilai er yang positif berarti apresiasi. 


$$
L R_{0}=n \frac{\left(S_{0}-S_{1}\right)}{S_{1}},
$$

dimana $S_{0}$ and $S_{1}$ adalah SSR untuk $H_{0}: \gamma_{1}=\gamma_{2}$ dan $H_{1}: \gamma_{1} \neq \gamma_{2}$. Dengan kata lain, $S_{0}$ dan $S_{1}$ adalah SSR dari persamaan (2) tanpa threshold effect dan dengan threshold effects. Distribusi asymptotic dari $L R_{0}$ adalah non-standard dan mendominasi distribusi $\chi^{2}$. Distribusi dari secara umum tergantung pada moments of sample, sehingga nilai-nilai kritis tidak dapat ditabulasikan.

Mengingat $\gamma$ belum terindentifikasi, distribusi asymptotic dari $L R_{0}$ bukanlah $\chi^{2}$. Hansen (1997) memperlihatkan bahwa hal ini dapat di-aproksimasi dengan menggunakan prosedur bootstrap berikut ini:

1. Tetapkan $\mu_{t}^{*}, t=1, \ldots ., \mathrm{n}$ sebagai angka random yang diambil dari distribusi normal yang mempunyai rata-rat nol dan varian satu, yaitu i.e. $\mathrm{N}(0,1)$.

2. Tetapkan $y_{t}^{*}=\mu_{t}^{*}$.

3. Dengan menggunakan observasi $x_{t^{\prime}} t=1, \ldots, \mathrm{n}$ regres $y_{t}^{*}$ pada $x_{t}$ dan dapatkan residual variance $\quad \tilde{\sigma}_{n}^{* 2}$ dari model linear, dimana $\tilde{\sigma}_{n}^{* 2}=\frac{1}{n} \sum_{t=1}^{n}\left(y_{t}^{*}-x_{t} \tilde{\beta}\right)^{2}$

4. Dengan menggunakan observasi $x_{t^{\prime}} t=1, \ldots, n$ regres $y_{t}^{*}$ pada $x_{t}(\gamma)$ dan dapatkan residual variance $\tilde{\sigma}_{\mathrm{n}}^{* 2}(\gamma)$ dari threshold model, dimana

$$
\hat{\sigma}_{n}^{* 2}(\gamma)=\frac{1}{n} \sum_{t=1}^{n}\left(y_{t}^{*}-x_{t} \tilde{\beta}_{e r}\right)^{2}
$$

dan $\gamma$ adalah threshold value.

5. Hitung $F_{n}^{*}(\gamma) \equiv n\left(\frac{\tilde{\sigma}_{n}^{* 2}-\hat{\sigma}_{n}^{* 2}(\gamma)}{\hat{\sigma}_{n}^{* 2}(\gamma)}\right)$

6. Ulangi langkah nomor 4 dan 5 untuk $\gamma$ yang lain.

7. Cari $F_{n}^{*}=\sup _{\gamma \in \Gamma} F_{n}^{*}(\gamma)$

8. Ulangi langkah ke-1 sampai ke-7 berulang kali.

Hansen (1997) juga memperlihatkan bahwa pengambilan sample yang berulang-ulang dari $F_{n}{ }^{*}$ dapat digunakan sebagai aproksimasi untuk distribusi asymptotic dari $F_{n}$. Adapun $p$ value dari test ini adalah dengan menghitung prosentase dari bootstrap sample yang nilai $F_{n}{ }^{*}$ nya melebihi $L R_{0}$ (lihat persamaan (5)). 
Studi ini mengikuti Hansen (2000) dalam membentuk confidence region untuk er*. Confidence intervals untuk threshold parameter dibangun dengan meng-inversi distribusi asymptotic dari statistik likelihood ratio. Dalam hal ini, kami menguji hipothesa nol $H_{0}$ : er* $=e r$ dengan menghitung likelihood test sebagai berikut:

$$
L R(e r)=n \frac{S_{1}(e r)-S_{1}\left(e r^{*}\right)}{S_{1}\left(e r^{*}\right)},
$$

dimana $S_{1}(e r)$ and $S_{1}\left(e r^{*}\right)$ adalah SSR dari persamaan (II.2) dengan threshold $e r$ and $e r^{*}$. Tetapkan $c_{\xi}(\beta)$ sebagai $\beta$-level nilai kritikal untuk $\xi$ dari Table 1 pada Hansen (2000). Tetapkan

$$
\hat{\Gamma}=\left[e r: L R(e r)<c_{\xi}(\beta)\right]
$$

Hansen (2000) memperlihatkan bahwa adalah asymptotically valid untuk $\beta$-level confidence pada er. Untuk mendapatkan confidence interval, kami plot likelihood ratio LR(er) dengan threshold value (er), tarik garis lurus pada $c_{\xi}(\beta)$, dan beri tanda pada nilai threshold dengan likelihood ratio yang berada di bawah nilai kritikal. Perlu diperhatikan bahwa LR(er) akan sama dengan nol pada saat $e r=e r^{*}$.

Untuk menguji keberadaan threshold effect dari money growth terhadap inflasi, kami menggunakan model yang sama, namun kami mengganti depresiasi nilai tukar dengan pertumbuhan uang beredar sebagai threshold variable. Model berikut selanjutkan akan diestimasi:

$$
\begin{aligned}
\pi_{t}= & c+\alpha_{1} \pi_{t-1}+\alpha_{2} \pi_{t+1}^{e}+\beta g a p_{t}+\gamma e r_{t}+\theta_{1}\left(1-d_{t}\right)\left[\left(m_{t}\right) I\left(m_{t}>m^{*}\right)\right] \\
& +\theta_{2} d_{t}\left[\left(m_{t}\right) I\left(m_{t} \leq m^{*}\right)\right]+\delta_{1} \text { crisis }+\delta_{2} \text { fuel }+\delta_{3} \text { fitri }+\varepsilon_{t}
\end{aligned}
$$

dimana $d_{t}= \begin{cases}1 & \text { if } m_{t} \leq m^{*} \\ 0 & \text { if } m_{t}>m^{*}\end{cases}$

Adapun prosedur estimasi dan pengujian untuk threshold pertumbuhan uang beredar adalah sama seperti prosedur di atas.

\subsection{Data}

Kami menggunakan data CPI, output gap, nilai tukar, dan M1. Data-data tersebut kami peroleh dari Bank Indonesia (BI) dan BPS. Untuk analisis, kami menggunakan data bulanan dari 1980 sampai dengan 2008 (lihat Tabel 1). 


\begin{tabular}{c|l|c|c|c|}
\multicolumn{9}{|c|}{ Tabel 1. Data } \\
No & \multicolumn{1}{|c|}{ Data } & Frequency & Periode & Sumber \\
1 & Inflasi CPI & Bulanan & $1980: 1$ to $2008: 12$ & $\mathrm{BPS}$ dan $\mathrm{BI}$ \\
2 & Output gap & Bulanan & $1980: 1$ to $2008: 12$ & Penulis \\
3 & Nilai Tukar & Bulanan & $1980: 1$ to $2008: 12$ & $\mathrm{BI}$ \\
4 & M1 & Bulanan & $1980: 1$ to $2008: 12$ & $\mathrm{BI}$ \\
\end{tabular}

\begin{tabular}{|c|c|c|c|c|c|c|}
\hline \multicolumn{7}{|c|}{$\begin{array}{c}\text { Tabel } 2 . \\
\text { Statistik deskriptif data (year-on-year) }\end{array}$} \\
\hline \multirow{2}{*}{ Data } & \multicolumn{2}{|c|}{$1980-1997$} & \multicolumn{2}{|c|}{1998} & \multicolumn{2}{|c|}{1999 - 2008} \\
\hline & Mean & Std Dev & Mean & Std Dev & Mean & Std Dev \\
\hline CPI Inflation & 9,01 & 3,37 & 57,59 & 23,28 & 10,52 & 9,52 \\
\hline Exchange Rate Depreciation & $-6,63$ & 10,67 & $-67,97$ & 13,04 & 1,32 & 18,91 \\
\hline M1 Growth & 19,53 & 11,52 & 29,17 & 9,02 & 17,70 & 6,39 \\
\hline Output Gap - HPA & 0,19 & 3,39 & $-11,76$ & 1,97 & $-2,31$ & 3,25 \\
\hline Output Gap - Peak-to-Peak & $-2,50$ & 1,54 & $-13,13$ & 2,03 & $-5,20$ & 3,29 \\
\hline
\end{tabular}

\section{IV . HASIL DAN ANALISIS}

\subsection{Threshold Effect pada Depresiasi Nilai Tukar}

Tabel 3 di bawah ini menunjukkan hasil estimasi TSLS dari persamaan (2) tanpa adanya threshold effect (dengan men-set $\gamma_{1}=\gamma_{2}$ ). Dari table tersebut dapat kita lihat semua parameter signifikan, kecuali konstanta. Dengan menggunakan adjusted HP filter sebagai proxy dalam perhitungan potensial output, kami menemukan bahwa koefisien dari depresiasi nilai tukar (yoy) adalah sebesar $-0,050$ dan koefisien dari pertumbuhan M1 adalah 0,021. Hasil ini

\begin{tabular}{|l|c|c|c|c|}
\multicolumn{5}{c|}{ Tabel 3. } \\
& Phillips Curve Tanpa Threshold \\
& Coef & Std. Error & t-Statistic & Prob. \\
\hline Constant & -0.148 & 0.141 & -1.051 & 0.294 \\
Inflation & $-1) 0.710$ & 0.042 & 17.078 & 0.000 \\
Inflation(1) & 0.225 & 0.058 & 3.911 & 0.000 \\
Output Gap (-9) & 0.062 & 0.023 & 2.703 & 0.007 \\
Exchange Rate Dep(-1) & -0.050 & 0.009 & -5.223 & 0.000 \\
M1 Growth(-2) & 0.024 & 0.007 & 3.261 & 0.001 \\
Dummy Crisis & 1.293 & 0.539 & 2.400 & 0.017 \\
Dummy Fuel & 2.940 & 0.676 & 4.349 & 0.000 \\
Dummy Fitri & 0.548 & 0.213 & 2.567 & 0.011 \\
\hline Adjusted R-squared & 0.991 & & & \\
S.E. of regression & 1.093 & & & \\
SSR & 393.024 & & & \\
\hline
\end{tabular}




\begin{tabular}{l|c|c|c|c}
\multicolumn{5}{c}{ Tabel 4. } \\
\multicolumn{5}{|c}{ Phillips curve dengan threshold depresiasi nilai tukar } \\
& Coef & Std. Error & t-Statistic & Prob. \\
Constant & -0.169 & 0.144 & -1.179 & 0.239 \\
Inflation(-1) & 0.719 & 0.045 & 16.071 & 0.000 \\
Inflation(1) & 0.211 & 0.062 & 3.382 & 0.001 \\
Output Gap(-9) & 0.064 & 0.024 & 2.703 & 0.007 \\
Exchange Rate Dep(-1)<=-8.4\% & -0.056 & 0.012 & -4.652 & 0.000 \\
-8.4\% > Exchange Rate Dep(-1) & -0.045 & 0.010 & -4.567 & 0.000 \\
M1 Growth(-2) & 0.026 & 0.008 & 3.294 & 0.001 \\
Dummy Crisis & 1.154 & 0.547 & 2.109 & 0.036 \\
Dummy Fuel & 2.973 & 0.693 & 4.293 & 0.000 \\
Dummy Fitri & 0.548 & 0.218 & 2.516 & 0.012 \\
\hline Adjusted R-squared & & & & \\
S.E. of regression & 0.991 & & &
\end{tabular}

menunjukkan bahwa secara rata-rata dampak depresiasi nilai tukar terhadap inflasi lebih besar dibandingkan dengan dampak pertumbuhan uang beredar.

Untuk mengestimasi threshold depresiasi nilai tukar, kami menggunakan persamaan (2). Nilai threshold dicari mulai dari -30\% s.d. 0\%; dengan kenaikan 0,06\% terdapat 500 kandidat nilai threshold. Dari 500 nilai threshold tersebut, ditemukan nilai SSR yang paling minimum, yaitu 408,25, pada nilai $-8,4 \%$. Hal ini berarti threshold depresiasi nilai tukar adalah sebesar 8,4\%.

Tabel 4 menunjukkan hasil estimasi model dengan menggunakan adjusted HP filter untuk menghitung output potensial. Dari table dapat kita lihat bahwa dampak depresiasi nilai tukar pada inflasi pada saat tingkat depresiasi nilai tukar lebih besar atau sama dengan 8,4\% adalah sebesar 0,056, sedangkan dampaknya pada saat tingkat depresiasi nilai tukar di bawah 8,4\% adalah sebesar 0,045. Kedua koefisien tersebut di atas adalah signifikan pada tingkat $1 \%$.

Garis horizontal pada Grafik 1 menunjukkan 90\% confidence interval. Daerah di bawah garis horizontal membentuk daerah penerimaan. Statistik $L R(\gamma)$ akan bernilai nol pada threshold yang optimal. Dari gambar tersebut dapat kita lihat bahwa confidence interval untuk threshold nilai tukar ini terlalu lebar. Daerah di bawah garis dimana $L R(\gamma)=5,94^{5}$ bernilai $-23,52 \%$ s.d. $-2,64 \%$. Hal ini menunjukkan bahwa estimasi nilai threshold effect untuk depresiasi nilai tukar adalah kurang akurat.

Untuk menguji apakah benar terdapat perbedaan antara model linear dengan model threshold, kami melakukan bootstrapping sebanyak 1.000 kali. Kami mengikuti prosedur yang disarankan oleh Hansen (1997) untuk menghasilkan nilai kritis.

5 Ini adalah nilai kritis untuk 90\% confidence interval dari Table 1 Hansen (2000). 


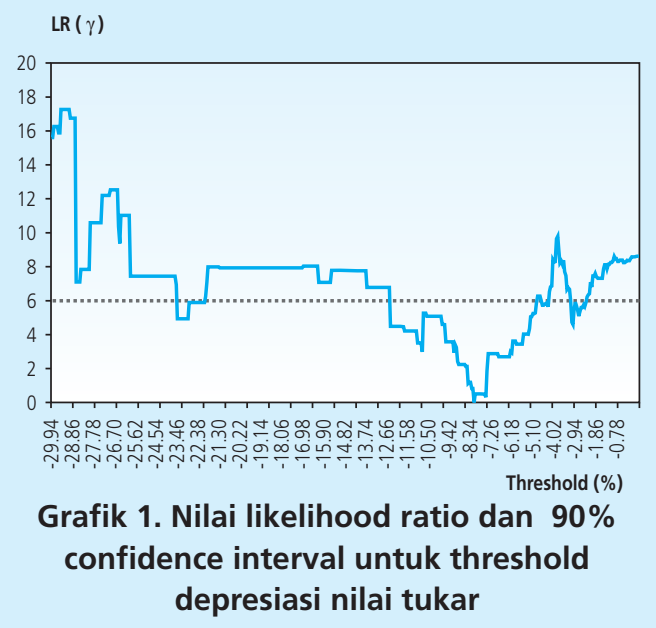

Ditemukan bahwa sebagian besar $F_{\text {sup }}$ berada di atas nilai $F_{o}$, yaitu -12,12, dimana nilai $p$-value sebesar 0,957. Hal ini menunjukkan bahwa kita tidak dapat menolak hipotesa nol dimana $\gamma_{1}=\gamma_{2}$. Dengan demikian, dapat disimpulkan bahwa tidak ada perbedaan dampak depresiasi nilai tukar yang signifikan terhadap inflasi pada level di bawah threshold dan di atas threshold. Dengan kata lain, dampak depresiasi nilai tukar pada inflasi adalah linear, yaitu sebesar 0,05\% untuk setiap 1\% tingkat depresiasi.

Sebagai robustness check, kami menggunakan berbagai model alternatif, yaitu model dengan menggunakan peak-to-peak output gap dan model dengan mengadopsi hubugan asymmetris antara inflasi dan output, yaitu L-shaped function ${ }^{6}$. Adapun alternative model dapat dilihat pada Tabel 5.

Tabel 6 menunjukkan hasil estimasi dengan dan tanpa threshold effect. Dari table tersebut dapat kita lihat bahwa koeffisien dari depresiasi nilai tukar di bawah atau sama dengan nilai

\begin{tabular}{c|l|c|c}
\multicolumn{5}{c}{ Tabel 5. } \\
Model alternative untuk threshold depresiasi nilai tukar \\
Model & Output Gap Measurement & Output Gap Function & ER Dep.Threshold \\
1 & Peak-to-Peak & Linear & No \\
2 & Peak-to-Peak & Linear & Yes \\
3 & Adjusted HP Filter & Non-Linear & No \\
4 & Adjusted HP Filter & Non-Linear
\end{tabular}

6 Menurut hasil dari Bab 3 Doctoral Thesis Wimanda (2010), Phillips curve di Indonesia lebih cocok dimodelkan dengan L-shape function dengan wall parameter sebesar $8.5 \%$. Funsi ini sebenarnya adalah fungsi parabola dimana dampak output gap kepada inflasi akan sangat besar jika output gap mendekati $8.5 \%$. 


\begin{tabular}{|c|c|c|c|c|}
\hline Variable & Model-1 & Model-2 & Model-3 & Model-4 \\
\hline Constant & $\begin{array}{c}0.007 \\
(0.186)\end{array}$ & $\begin{array}{c}0.011 \\
(0.192)\end{array}$ & $\begin{array}{c}-0.325 * * * \\
(0.122)\end{array}$ & $\begin{array}{c}-0.358 * * * \\
(0.127)\end{array}$ \\
\hline Inflation (-1) & $\begin{array}{c}0.714^{* * *} \\
(0.043)\end{array}$ & $\begin{array}{c}0.730 * * * \\
(0.048)\end{array}$ & $\begin{array}{c}0.694^{* * *} \\
(0.037)\end{array}$ & $\begin{array}{c}0.705 * * * \\
(0.041)\end{array}$ \\
\hline Inflation(1) & $\begin{array}{c}0.223 * * * \\
(0.059)\end{array}$ & $\begin{array}{c}0.199 * * * \\
(0.067)\end{array}$ & $\begin{array}{c}0.249 * * * \\
(0.051)\end{array}$ & $\begin{array}{c}0.233 * * * \\
(0.056)\end{array}$ \\
\hline Output Gap Linear (-9) & $\begin{array}{c}0.071 * * \\
(0.03)\end{array}$ & $\begin{array}{c}0.081 * * \\
(0.032)\end{array}$ & & \\
\hline Output Gap Non-Linear(-9) & & & $\begin{array}{l}0.0003 * * \\
(0.00016)\end{array}$ & $\begin{array}{l}0.0004 * * \\
(0.00017)\end{array}$ \\
\hline Exchange Rate Dep(-1) & $\begin{array}{c}-0.048 * * * \\
(0.009)\end{array}$ & & $\begin{array}{c}-0.047 * * * \\
(0.009)\end{array}$ & \\
\hline Exchange Rate Dep $(-1)<=$ Threshold & & $\begin{array}{c}-0.057 * * * \\
(0.013)\end{array}$ & & $\begin{array}{c}-0.054 * * * \\
(0.011)\end{array}$ \\
\hline Threshold $<$ Exchange Rate Dep(-1) & & $\begin{array}{c}-0.041 * * * \\
(0.009)\end{array}$ & & $\begin{array}{c}-0.041 * * * \\
(0.009)\end{array}$ \\
\hline M1 Growth(-2) & $\begin{array}{c}0.027 * * * \\
(0.008)\end{array}$ & $\begin{array}{c}0.030 * \star * \\
(0.009)\end{array}$ & $\begin{array}{c}0.027 * * * \\
(0.008)\end{array}$ & $\begin{array}{c}0.031 * * * \\
(0.008)\end{array}$ \\
\hline Dummy Crisis & $\begin{array}{l}1.228 * * \\
(0.536)\end{array}$ & $\begin{array}{l}1.154 * * \\
(0.547)\end{array}$ & $\begin{array}{c}0.652 \\
(0.405)\end{array}$ & $\begin{array}{c}0.462 \\
(0.422)\end{array}$ \\
\hline Dummy Fuel & $\begin{array}{c}2.944 * * * \\
(0.683)\end{array}$ & $\begin{array}{c}2.973 * * * \\
(0.693)\end{array}$ & $\begin{array}{c}2.772 * * * \\
(0.648)\end{array}$ & $\begin{array}{c}2.805^{\star * \star} \\
(0.665)\end{array}$ \\
\hline Dummy Fitri & $\begin{array}{c}0.551 * * \\
(0.215)\end{array}$ & $\begin{array}{c}0.548 * * \\
(0.218)\end{array}$ & $\begin{array}{c}0.554 * * * \\
(0.208)\end{array}$ & $\begin{array}{c}0.554^{* * *} \\
(0.213)\end{array}$ \\
\hline Adjusted R-squared & 0.991 & 0.991 & 0.992 & 0.991 \\
\hline S.E. of regression & 1.103 & 1.116 & 1.066 & 1.091 \\
\hline SSR & 400.161 & 408.247 & 373.986 & 390.569 \\
\hline Threshold ER & & -8.40 & & -8.40 \\
\hline p-value & & 0.999 & & 0.966 \\
\hline
\end{tabular}

threshold-nya $\left(\gamma_{1}\right)$ dan di atas nilai threshold-nya pada model 2 dan model $4\left(\gamma_{2}\right)$ adalah negative dan signifikan. Kami menemukan bahwa nilai threshold adalah sama dengan nilai threshold pada model sebelumnya, yaitu $-8,4 \%$. Nilai koeffisien $\gamma_{1}$ berada pada kisaran $-0,054$ sampai dengan $-0,057$, sementara nilai koefisien $\gamma_{2}$ relative sama, yaitu $-0,041$.

Setelah melakukan bootstrapping sebanyak 1.000 kali, model 2 and model 4 menghasilkan kesimpulan yang sama dengan model utama. Secara keseluruhan, dari bootstrap test statistics pada variabel ini tidak ditemukan adanya signifikansi secara statistik. Nilai $p$ values berkisar antara 0,966 dan 0,999. Hal ini mengimplikasikan bahwa tidak ada perbedaan yang signifikan antara dampak depresiasi nilai tukar terhadap inflasi pada di atas dan di bawah nilai threshold-nya. 
Apabila kita membandingkan model 1 dan model 2, begitu pula model 3 dan model 4, dapat kita lihat bahwa nilai SSR untuk threshold model adalah lebih besar dibandingkan dengan nilai SSR pada model linear. Hal ini mengkonfirmasi kesimpulan di atas.

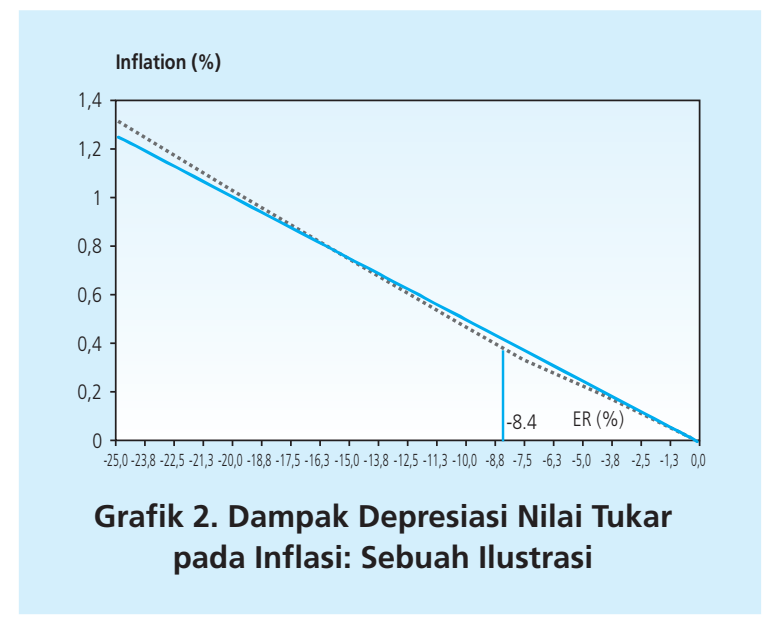

Grafik 2 di atas menggambarkan dampak depresiasi nilai tukar pada inflasi. Dari gambar tersebut, dapat kita lihat bahwa kemiringan (slope) garis warna biru solid adalah sama untuk setiap titik. Dampak linear tersebut (garis biru solid) lebih preferable dibandingkan dampak non-linear (garis coklat putus-putus).

\subsection{Threshold Effect pada Pertumbuhan Uang}

Untuk mengestimasi nilai threshold untuk pertumbuhan uang beredar, kami menggunakan persamaan (8) dengan output gap dihitung berdasarkan adjusted HP filter. Pencarian nilai threshold dilakukan mulai dari 0\% sampai dengan 40\%, dengan kenaikan sebesar 0,08. Hal ini berarti terdapat 500 kandidat nilai threshold. Kami menemukan bahwa nilai threshold untuk pertumbuhan M1 adalah 9,84\%?

Tabel 7 menunjukkan hasil estimasi threshold dengan menggunakan adjusted HP filter sebagai pengukuran output gap. Mengingat hasil dari variable utama cukup robust, yaitu semua koefisien signifikan secara statistik, maka kita dapat langsung menganalisa hasil thresholdnya. Dari table tersebut, koefisien pertumbuhan uang beredar pada saat di bawah atau sama dengan 9,84\% ( $\theta_{1}$ ) adalah 0,099, sedangkan koefisien pertumbuhan uang beredar pada saat di atas $9,84 \%\left(\theta_{2}\right)$ adalah 0,032. Kedua koefisien tersebut signifikan pada level $1 \%$.

7 Nilai ini menghasilkan angka SSR yang terkecil. 


\begin{tabular}{l|c|c|c|c}
\multicolumn{5}{c}{ Tabel 7. } \\
\multicolumn{1}{|c}{ Phillips Curve dengan Threshold Pertumbuhan M1: Titik Pertama } \\
\multicolumn{1}{|c|}{ Coef } & Std. Error & t-Statistic & Prob. \\
Constant & -0.361 & 0.150 & -2.405 & 0.017 \\
Inflation(-1) & 0.695 & 0.039 & 17.947 & 0.000 \\
Inflation(1) & 0.241 & 0.054 & 4.468 & 0.000 \\
Output Gap(-9) & 0.053 & 0.022 & 2.455 & 0.015 \\
Exchange Rate Dep(-1) & -0.047 & 0.009 & -5.257 & 0.000 \\
M1 Growth(-2)<=9.84\% & 0.099 & 0.030 & 3.341 & 0.001 \\
9.84\% < M1 Growth(-2) & 0.032 & 0.008 & 3.877 & 0.000 \\
Dummy Crisis & 1.229 & 0.516 & 2.384 & 0.018 \\
Dummy Fuel & 2.983 & 0.656 & 4.549 & 0.000 \\
Dummy Fitri & 0.583 & 0.207 & 2.821 & 0.005 \\
\hline Adjusted R-squared & 0.992 & & & \\
S.E. of regression & 1.057 & & & \\
SSR & 366.404 & &
\end{tabular}

Hasil ini berimplikasi bahwa ada perbedaan dampak dari pertumbuhan M1 terhadap inflasi pada saat di atas atau di bawah nilai thresholdnya, yaitu 9,84\%. Sebagai ilustrasi, apabila M1 tumbuh sebesar 5\% di bulan ini, maka terdapat tambahan inflasi sebesar 0,5\% di dua bulan yang akan datang. Sedangkan apabila M1 tumbuh $10 \%$ di bulan ini, maka akan ada tambahan inflasi rata-rata sebesar 0,98\% pada 2 bulan mendatang.

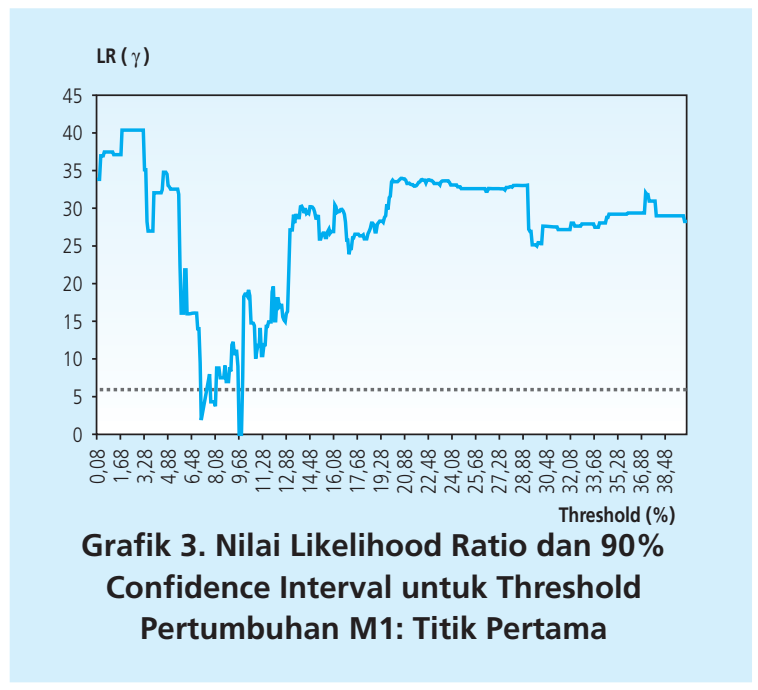

Setelah nilai threshold diidentifikasi, maka pertanyaan penting berikutnya adalah seberapa akurat estimasi tersebut. Hal ini membutuhkan perhitungan daerah kepercayaan (confidence region) di sekitar nilai threshold. Grafik 3 mengilustrasikan nilai likelihood ratio dan nilai 
threshold, serta 90\% confidence intervals. Seperti yang dijelaskan di atas, confidence region dihitung dengan mengambil nilai-nilai pertumbuhan $\mathrm{M} 1$ dimana nilai $L R(M 1)$ terletak di bawah garis horizontal. Dari gambar tersebut terlihat bahwa confidence interval untuk pertumbuhan uang adalah cukup sempit, yaitu $7,12 \%-10 \%$. Hal ini mengindikasikan bahwa nilai threshold yang diestimasi tersebut adalah cukup akurat.

Langkah selanjutnya adalah menguji apakah nilai threshold tersebut ada atau tidak dengan melakukan bootstrapping. Dengan men-generate sample baru dan diulangi sebanyak 1.000 kali untuk keperluan estimasi percentile dari asymptotic null distribution $F_{n}{ }_{n}$, kami mendapatkan bahwa nilai dari $p$-value adalah 0,001. Dengan demikian, hipotesa nol (model linear) dapat ditolak dan disimpukan bahwa ada nilai threshold untuk pertumbuhan M1.

Setelah menemukan nilai threshold yang pertama, kami mencari kemungkinan adanya nilai threshold yang lain. Kita dapat mencari 3 regime pada saat bersamaan, namun cara ini sangat tidak efisien dalam hal waktu perhitungan. Chong (1994) dan Bai (1997) menunjukkan bahwa estimasi secara sekuensial adalah konsisten, sehingga hal ini dapat menghindari dari masalah perhitungan. Hal ini berarti kita dapat mem-fix-kan angka threshold yang pertama kemudian mencari nilai threshold kedua dengan mengasumsikan bahwa threshold pertama sudah fix.

Kami memulainya dengan mempertimbangkan kemungkinan adanya nilai threshold yang lain antara 9,84\% sampai dengan 40\%. Dengan penambahan nilai sebanyak 0,075 terdapat 400 kandidat nilai threshold. Ditemukan bahwa SSR terkecil pada threshold 17,13\%. Hal ini berarti bahwa 17,13\% adalah kandidat threshold kedua. Hasil estimasi TSLS dapat dilihat pada Tabel A (lihat Lampiran). Meskipun semua koefisien pertumbuhan M1 tersebut signifikan pada level $1 \%$, namun setelah melakukan bootstrapping kami mendapatkan nilai $p$-value sebesar 0,177 yang mana agak lebih besar dari 10\%. Dengan demikian, hipotasa nol dari 2 regime threshold tidak dapat ditolak. Dengan kata lain, hubungan antara inflasi dan pertumbuhan M1 adalah linear pada saat M1 tumbuh di atas 9,84\%.

Usaha pencarian kandidat threshold berikutnya adalah antara 0\% sampai dengan $9,84 \%$. Kami menyeleksi 350 nilai dan menemukan SSR yang paling minimal ada pada titik 7,08\%. Hasil estimasi TSLS dengan 2 threshold, yaitu 9,84\% dan 7,08\% dapat dilihat pada Tabel 8. Dari table tersebut dapat kita perhatikan bahwa koefisien dari pertumbuhan M1 pada saat tumbuh di bawah 7,08\% adalah 0,146; pada saat tumbuh antara 7,08\% dan 9,84\% koefisiennya adalah 0,088; dan pada saat tumbuh di atas 9,84\% koefisiennya turun menjadi 0,033 . Semua koefisien tersebut di atas adalah signifikan padal level $1 \%$. Hal ini menunjukkan bahwa semakin tinggi pertumbuhan $\mathrm{M} 1$, dampaknya terhadap inflasi akan semakin berkurang. 


\begin{tabular}{l|c|c|c|c}
\multicolumn{5}{c}{ Tabel 8. } \\
\multicolumn{1}{|c}{ Phillips Curve dengan Threshold Pertumbuhan M1: Titik Ke Dua } \\
& Coef & Std. Error & t-Statistic & Prob. \\
Constant & -0.404 & 0.151 & -2.671 & 0.008 \\
Inflation(-1) & 0.687 & 0.038 & 18.160 & 0.000 \\
Inflation(1) & 0.252 & 0.053 & 4.772 & 0.000 \\
Output Gap(-9) & 0.049 & 0.021 & 2.318 & 0.021 \\
Exchange Rate Dep(-1) & -0.045 & 0.009 & -5.152 & 0.000 \\
M1 Growth(-2)<=7.08\% & 0.146 & 0.049 & 2.997 & 0.003 \\
7.08\% $<$ M1 Growth(-2)<=9.84\% & 0.088 & 0.030 & 2.922 & 0.004 \\
9.84\% < M1 Growth(-2) & 0.033 & 0.008 & 4.003 & 0.000 \\
Dummy Crisis & 1.151 & 0.506 & 2.276 & 0.024 \\
Dummy Fuel & 2.954 & 0.645 & 4.580 & 0.000 \\
Dummy Fitri & 0.602 & 0.204 & 2.951 & 0.003 \\
\hline Adjusted R-squared & 0.992 & & & \\
S.E. of regression & 1.041 & & & \\
SSR & 354.107 & & &
\end{tabular}

Grafik 4 menunjukkan bahwa likelihood ratio minimum ditemukan pada titik threshold 7,08\%. Adapun 90\% confidence interval-nya cukup sempit, yaitu antara 6,94\% sampai dengan $8,04 \%$. Hal ini mengindikasikan bahwa 7,08\% adalah kandidat yang potensial untuk threshold kedua.

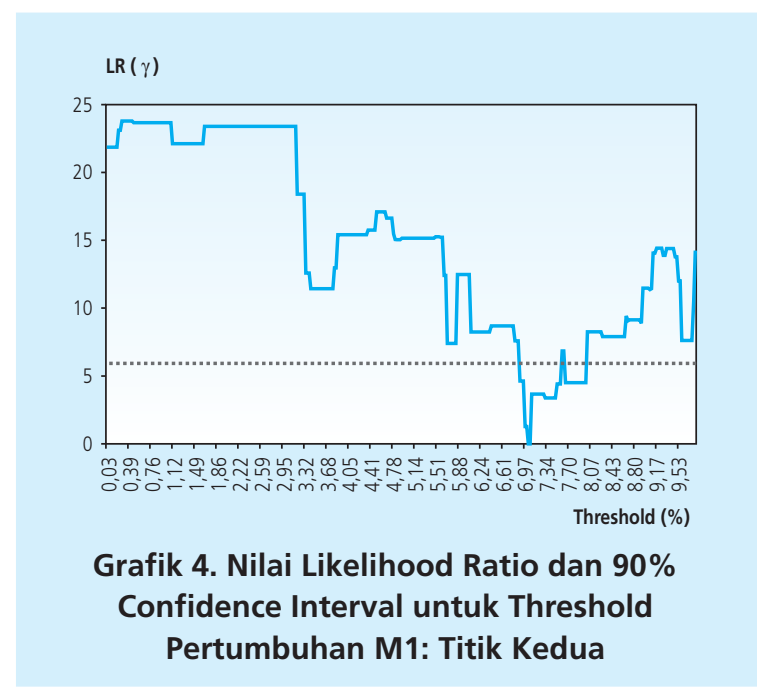

Uji secara formal dilakukan dengan bootstrapping sample. Dengan mereplikasi sample dan mengulanginya sebanyak 1.000 kali, kami mendapatkan $p$-value sebesar 0,004. Dengan demikian, kami menolak hypothesa nol dari 2 regime. Atas dasar test tersebut, kami menyimpulkan bahwa terdapat 3 regime threshold untuk pertumbuhan M1. 
Selanjutkan kami mencari kandidat nilai threshold yang lain di antara 0\% dan 7,08\% . Dengan penambahan sebesar 0,028\%, kami mengevaluasi 250 kandidat. Dari 250 kandidat tersebut, kami menemukan nilai SSR yang paling minimum terdapat pada titik 4,93\%.

Tabel B (lihat Lampiran) melaporkan hasil estimasi TSLS dengan empat regime. Semua koefisien signifikan, kecuali koefisien untuk pertumbuhan $\mathrm{M} 1$ antara $0 \%$ sampai dengan 4,93\% ( $p$-value $=0,273)$. Adapun test formal melalui bootstrapping menghasilkan $p$-value sebesar 0,191 . Hal ini mengindikasikan bahwa hubungan inflasi dengan pertumbuhan M1 adalah linear pada saat M1 tumbuh antara 0\% sampai dengan 7,12\%. Mengingat threshold ketiga ini tidak signifikan, kita tidak mungkin memisahkan sample lebih jauh lagi.

\begin{tabular}{c|l|c|c}
\multicolumn{2}{c}{ Model Alternative untuk Threshold Pertumbuhan M1 } \\
Model & Output Gap Measurement & Output Gap Function & M1 Threshold \\
5 & Peak-to-Peak & Linear & No \\
6 & Peak-to-Peak & Linear & Yes \\
7 & Adjusted HP Filter & Non-Linear & No \\
8 & Adjusted HP Filter & Non-Linear & Yes
\end{tabular}

Sebagai robustness check, kembali kami menggunakan berbagai model dengan perbedaan terletak pada pengukuran output gap dan non-linear Phillips curve. Tabel 9 menunjukkan perbedaan tersebut.

Seperti terlihat pada Tabel 10, hasil empiris ini menghasilkan beberapa hal yang menarik. Pertama, semua koefisien, kecuali konstanta dan dummy variabel untuk krisis pada sebagian model, adalah signifikan. Kedua, estimasi dari nilai threshold adalah sama, yaitu 9,84\% and $7,08 \%$. Ketiga, koefisien dari threshold effect agak berbeda, namun perbedaannya sangat kecil. Koefisien dari pertumbuhan M1 pada saat tumbuh di bawah 7,08\% adalah berkisar 0,156-0,160; koefisien dari pertumbuhan M1 pada saat tumbuh antara 7,08\% dan 9,84\% berkisar 0,094-0,096; dan koefisien dari pertumbuhan M1 pada saat tumbuh di atas 9,84\% adalah berkisar 0,035-0,037.

Mengingat semua nilai $p$-values dari bootstrapping kurang dari 1\%, maka kita dapat menolak hipotasa nol untuk dua regime dan prefer kepada tiga regime. Selain itu, jika dibandingkan nilai SSR pada threshold model (model 6 dan model 8) dan nilai SSR pada linear model (model 5 dan model 7), kami menemukan bahwa model threshold lebih baik dari model linear. 


\begin{tabular}{|c|c|c|c|c|}
\hline \multicolumn{5}{|c|}{$\begin{array}{l}\text { Tabel 10: } \\
\text { Robustness check untuk threshold pertumbuhan M1 }\end{array}$} \\
\hline Variable & Model-1 & Model-2 & Model-3 & Model-4 \\
\hline Constant & $\begin{array}{c}0.062 \\
(0.187)\end{array}$ & $\begin{array}{l}-0.284 \\
(0.183)\end{array}$ & $\begin{array}{c}-0.279 * * \\
(0.12)\end{array}$ & $\begin{array}{c}-0.559 * * * \\
(0.137)\end{array}$ \\
\hline Inflation & $\begin{array}{c}(-1) 0.714^{* * *} \\
(0.043)\end{array}$ & $\begin{array}{c}0.689 * * * \\
(0.039)\end{array}$ & $\begin{array}{c}0.694^{* * *} \\
(0.037)\end{array}$ & $\begin{array}{c}0.672 * * * \\
(0.034)\end{array}$ \\
\hline Inflation(1) & $\begin{array}{c}0.223 * * * \\
(0.059)\end{array}$ & $\begin{array}{c}0.250 * * * \\
(0.053)\end{array}$ & $\begin{array}{c}0.251 * * * \\
(0.051)\end{array}$ & $\begin{array}{c}0.273 * * * \\
(0.047)\end{array}$ \\
\hline Output Gap Linear(-9) & $\begin{array}{c}0.074 * * \\
(0.03)\end{array}$ & $\begin{array}{c}0.060 * * \\
(0.028)\end{array}$ & & \\
\hline Output Gap Non-Linear(-9) & & & $\begin{array}{c}0.000334 * * \\
(0.000161)\end{array}$ & $\begin{array}{l}0.00033^{* *} \\
(0.000153)\end{array}$ \\
\hline Exchange Rate Dep(-1) & $\begin{array}{c}-0.048^{* * *} \\
(0.009)\end{array}$ & $\begin{array}{c}-0.043 * * * \\
(0.008)\end{array}$ & $\begin{array}{c}-0.047 * * * \\
(0.009)\end{array}$ & $\begin{array}{c}-0.042 * * * \\
(0.008)\end{array}$ \\
\hline M1 Growth(-2) & $\begin{array}{c}0.024 * * * \\
(0.007)\end{array}$ & & $\begin{array}{c}0.026^{* * *} \\
(0.007)\end{array}$ & \\
\hline M1 Growth $(-2)<=2$ nd Threshold & & $\begin{array}{c}0.156^{* * *} \\
(0.049)\end{array}$ & & $\begin{array}{c}0.160 * * * \\
(0.048)\end{array}$ \\
\hline 2nd Threshold $<$ M1 Growth(-2) $<=1$ st Threshold & & $\begin{array}{c}0.096^{* * *} \\
(0.031)\end{array}$ & & $\begin{array}{c}0.094^{* * *} \\
(0.03)\end{array}$ \\
\hline 1st Threshold < M1 Growth(-2) & & $\begin{array}{c}0.035^{* * *} \\
(0.008)\end{array}$ & & $\begin{array}{c}0.037 * * * \\
(0.008)\end{array}$ \\
\hline Dummy Crisis & $\begin{array}{l}1.235 * * \\
(0.539)\end{array}$ & $\begin{array}{c}1.122 * * \\
(0.503)\end{array}$ & $\begin{array}{c}0.644 \\
(0.406)\end{array}$ & $\begin{array}{c}0.633 \\
(0.386)\end{array}$ \\
\hline Dummy Fuel & $\begin{array}{c}2.929 * * * \\
(0.685)\end{array}$ & $\begin{array}{c}2.968 * * * \\
(0.65)\end{array}$ & $\begin{array}{c}2.752 * * * \\
(0.649)\end{array}$ & $\begin{array}{c}2.819 * * * \\
(0.619)\end{array}$ \\
\hline Dummy Fitri & $\begin{array}{l}0.550 * * \\
(0.216)\end{array}$ & $\begin{array}{c}0.608^{* * *} \\
(0.205)\end{array}$ & $\begin{array}{c}0.553 * * * \\
(0.209)\end{array}$ & $\begin{array}{c}0.611 * * * \\
(0.199)\end{array}$ \\
\hline Adjusted R-squared & 0.991 & 0.992 & 0.992 & 0.992 \\
\hline S.E. of regression & 1.107 & 1.045 & 1.070 & 1.014 \\
\hline SSR & 403.146 & 357.419 & 376.347 & 336.461 \\
\hline 1st Threshold & & 9.84 & & 9.84 \\
\hline 2nd Threshold & & 7.08 & & 7.08 \\
\hline$p$-value & & 0.005 & & 0.005 \\
\hline
\end{tabular}

Catatan:

- Angka dalam tanda kurung adalah standard error.

$* * *, * *$, dan * mengindikasikan tingkat signifikansi pada level $1 \%, 5 \%$, dan $10 \%$.

Dari hasil analisis dan uji di atas, hasil empiris ini memberikan bukti yang kuat bahwa hubungan pertumbuhan M1 dan inflasi dapat digambarkan dengan tiga regime. Grafik 5 mengilustrasikan hubungan tersebut. Dari gambar tersebut, dapat kita lihat bahwa kemiringan dari garis solid warna coklat ketika M1 tumbuh sampai dengan 7,1\% adalah lebih curam dibandingkan dengan garis ketika M1 tumbuh antara 7,1\%-9,8\%. Demikian pula pada saat M1 tumbuh lebih dari 9,8\%, kemiringan garis menjadi lebih landai. 


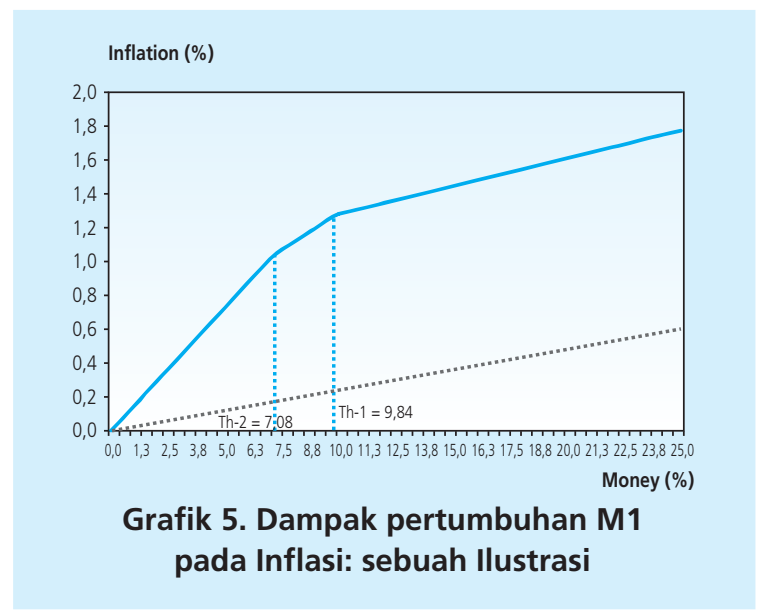

\section{KESIMPULAN}

Paper ini memberikan kontribusi pada literatur yang ada dimana penentuan threshold dilakukan dengan menggunakan teknik yang dikembangkan oleh Hansen (1997, 2000). Dibandingkan dengan penentuan threshold yang dilakukan secara arbitrary, teknik ini memberikan keuntungan dimana nilai threshold dapat ditentukan oleh karakteristik data itu sendiri. Lebih jauh lagi, teknik ini memungkinkan untuk mendeteksi kemungkinan nilai threshold lainnya. Apabila nilai threshold ditetapkan satu, padahal sebenarnya terdapat lebih dari satu, maka nilai koefisiennya dapat under/over estimate.

Paper ini memberikan pemahaman mengenai threshold effect dari depresiasi nilai tukar dan pertumbuhan uang beredar (M1) terhadap inflasi di Indonesia. Dengan menggunakan data bulanan dari 1980:01 sampai 2008:12 model ini memberikan bukti yang kuat bahwa terdapat threshold effect dari pertumbuhan uang beredar terhadap inflasi, namun tidak ditemukan threshold effect antara depresiasi nilai tukar dan inflasi.

Seluruh eksperimen dilakukan sebanyak 1.000 kali. Dengan menggunakan dua pengukuran output gap yang berbeda, yaitu adjusted HP filter dan peak-to-peak method, dan dua jenis hubungan inflation-output, yaitu linear and L-shape function, kesimpulan kami adalah sama. Nilai threshold dari depresiasi nilai tukar adalah 8,4\%. Namun demikian, koefisien dari nilai tukar pada saat tingkat depresiasi di bawah 8,4\% $\left(\gamma_{1}\right)$ dan koefisien dari nilai tukar pada saat di atas 8,4\% $\left(\gamma_{2}\right)$ tidak berbeda banyak. F-test memberikan kesimpulan bahwa tidak ada perbedaan yang signifikan antara $\gamma_{1}$ dan $\gamma_{2}$. Dengan demikian, dampak depresiasi nilai tukar pada inflasi adalah linear untuk semua tingkat depresiasi (yaitu 0,05).

Untuk pertumbuhan uang beredar, kami menemukan bukti bahwa ada dua nilai threshold, yaitu $7,1 \%$ and $9,8 \%$. F-tests memberikan kesimpulan bahwa efek dari ketiga regime tersebut 
adalah berbeda secara signifikan. Hasil empiris ini menunjukkan bahwa dampak pertumbuhan uang beredar terhadap inflasi tidaklah linear. Dampak terbesar pada saat uang beredar tumbuh antara 0\% s.d. 7,1\% (yaitu 0,15), dampak moderat terjadi pada saat uang beredar tumbuh antara 7,1\% s.d. 9,8\% (yaitu 0,09), dan dampak terendah pada saat uang beredar tumbuh di atas 9,8\% (yaitu 0,03). Semakin tinggi uang beredar yang tumbuh, maka dampaknya terhadap inflasi akan semakin berkurang.

Secara umum, temuan kami ini sejalan dengan Galbraith (1996) yang melakukan studi hubungan antara uang beredar dengan output. Dia menemukan bahwa uang mempunyai dampak yang besar pada output jika pertumbuhan uang beredar di bawah nilai threshold-nya dibandingkan dengan di atas threshold. Temuan kami dan temuannya adalah konsisten dengan proposisi bahwa kebijakan moneter mempunyai pengaruh yang kecil atau tidak memberikan pengaruh pada saat pertumbuhan uang beredar sangat tinggi.

Hasil temuan ini memberikan kesimpulan bahwa dampak uang beredar pada inflasi pada saat uang beredar tumbuh di bawah 9,8\% akan lebih besar dibandingkan dengan dampak depresiasi nilai tukar terhadap inflasi. Kesimpulan ini berbeda dengan studi sebelumnya yang tidak memasukkan threshold effect, dimana dampak depresiasi nilai tukar terhadap inflasi adalah lebih besar dibandingkan dengan pertumbuhan uang beredar pada setiap tingkat.

Meskipun dampak depresiasi nilai tukar terhadap inflasi adalah linear, tidak berarti bahwa, sebagai otoritas moneter, Bank Indonesia dapat mengesampingkan tingkat depresiasi nilai tukar mengingat dampaknya yang moderat. Lebih jauh lagi, studi ini menyarankan Bank Indonesia sebaiknya memperhatikan pertumbuhan uang beredar, dalam hal ini M1, mengingat dampak pertumbuhan M1 cukup besar pada saat berada pada tingkat di bawah nilai thresholdnya. Meskipun dampak pertumbuhan M1 pada inflasi tidak linear dengan dampak yang lebih kecil pada saat M1 tumbuh di atas nilai thresholdnya, studi ini tidak berarti menyarankan untuk membiarkan M1 agar tumbuh pesat.

Hasil temuan kami di atas berdasarkan methodology yang diajukan oleh Hansen (1997, 2000). Namun demikian, studi ini tidak menjelaskan mengapa pertumbuhan uang beredar yang semakin tinggi memberikan dampak yang lebih mild kepada inflasi. Dengan demikian, studi lanjutan di masa mendatang untuk area ini sangat diperlukan untuk menjelaskan alasan dampak yang asimetris ini.

Analisis di atas berdasarkan analisis parsial, yaitu menggunakan single equation model, meskipun pada kenyataannya nilai tukar dan uang beredar tidak independen. Penggunaan model yang lebih kompleks dimana nilai tukar dan uang beredar dijadikan sebagai variable endogen dan mengevaluasi nilai threshold, sebagaimana yang ditemukan di studi ini, akan menjadi studi yang menarik. Hal ini patut direserve untuk studi lanjutan. 


\section{DAFTAR PUSTAKA}

Alba, J. D., Papell, D. (1998), 'Exchange Rate Determination and Inflation in Southeast Asian Countries', Journal of Development Economics, 55(2), 421-437.

Arestis, P., Cipollini, A., Fattouh, B. (2004), 'Threshold Effect in the U.S. Budget Deficit', Economic Inquiry, 42(2), 214-222.

Bai, J. (1997), 'Estimating Multiple Breaks One at a Time', Econometric Theory, 13, 315-52.

Bajo-Rubio, O., Diaz-Roldan, C., Esteve, V. (2004), 'Searching for Threshold Effects in the Evolution

of Budget Deficits: An Application to the Spanish Case', Economics Letters, 82, 239-243.

Barro, R. J. (1993), Macroeconomics, 4th edition, New York: Wiley

Bernhofen, D. M., Xu, P. (2000), 'Exchange Rates and Market Power: Evidence from the Petrochemical Industry', Journal of International Economics, 52, 283-297.

Calvo, G. A., Reinhart, C. M. (2000), 'Fixing for Your Life', NBER Working Paper, 8006.

Campa, J. M., Goldberg, L. S. (2005), 'Exchange Rate Pass-Through into Import Prices: A Macro or Micro Phenomenon?', Review of Economics and Statistics, 87(4), 679-690.

Chong, T.T.L. (1994), 'Consistency of Change-Point Estimators when the Number of ChangePoints in Structural Change Models is Underspecified', Working Paper, Chinese University of Hong Kong.

Choudhri, E. U., Hakura, D. S. (2006), 'Exchange Rate Pass-through to Domestic Prices: Does the Inflationary Environment Matter?', Journal of International Money and Finance, 25, 614-639.

De Grauwe, P., Poland, M. (2005), 'Is Inflation always and Everywhere a Monetary Phenomenon?', Scandinavia Journal of Economics, 107(2), 239-259.

Dewald, W. G. (1998), 'Money Still Matters', Federal Reserve Bank of St. Louis Review, 80, 1324.

Dwyer, G. P., Hafer, R. W. (1988), 'Is Money Irrelevant?', Federal Reserve Bank of St. Louis Review, (May/June), 3-17.

Dwyer, G. P., Hafer, R. W. (1999), 'Are Money Growth and Inflation Still Related?', Economic Review, Federal Reserve Bank of Atlanta, Second Quarter.

Foster, N. (2006), 'Export, Growth and Threshold Effects in Africa', Journal of Development Studies, 42(6), 1056-1074. 
Friedman, M. (1968), 'The Role of Monetary Policy', American Economic Review, 58(1): 1-17. Friedman, M. (1992), Money Mischief: Episodes in Monetary History, New York: Harcourt Brace Jovanovich

Galbraith, J.W. (1996), 'Credit Rationing and Threshold Effects in the Relation between Money and Output', Journal of Applied Econometrics, 11(4), 419-429.

Goldberg, P. K. (1995), 'Product Differentiation and Oligopoly in International Markets: the Case of the U.S. Automobile Industry', Econometrica, 63(4), 891-951.

Goldberg, P. K., Knetter, M. (1997), 'Goods Prices and Exchange Rates: What Have We Learned?', Journal of Economic Literature, 35, 1243-1272.

Lucas, R. E. (1980), 'Two Illustrations of the Quantity Theory of Money', American Economic Review, 70, 1005-14.

Hansen, B.E. (1997), 'Inference in TAR Models', Studies in Nonlinear Dynamics and Econometrics, 2(1), 1-14.

Hansen, B.E. (2000), 'Sample Splitting and Threshold Estimation', Econometrica, 68(3).

Hooper, P., Mann, C. L. (1989), 'Exchange Rate Pass-Through in the 1980s: the Case of U.S. Imports of Manufactures', Brookings Papers of Economic Activity, 1.

Khan, M. S., Senhadji, A.S. (2001), 'Threshold Effect in the Relation between Inflation and Growth', IMF Staff Paper, 48(1).

McCandless, G. T., Weber, W. E. (1995), 'Some Monetary Facts', Federal Reserve Bank of Minneapolis Quarterly Review, 19(3), 2-11.

McCarthy, J. (2000), 'Pass-Through of Exchange Rates and Import Prices to Domestic Inflation in Some Industrialized Economies', Federal Reserve Bank of New York Staff Report, 3.

Menon, J. (1995), 'Exchange Rate Pass-Through', Journal of Economic Surveys, 9(2), 197-231. Papageorgiou, C. (2002), 'Trade as Threshold Variable for Multiple Regimes', Economics Letters, 77, 85-91.

Papell, D. H. (1994), 'Exchange Rates and Prices: An Empirical Analysis', International Economic Review, 35(2), 397-410.

Rolnick, A. J., Weber, W. E. (1997), 'Money, Inflation, and Output under Fiat and Commodity Standards', Journal of Political Economy, 105(6): 1308-21.

Wimanda, R.E. (2010), 'Inflation and Monetary Policy Rules: Evidence from Indonesia', Doctoral Thesis, Loughborough University. 


\section{Lampiran}

\begin{tabular}{|c|c|c|c|c|}
\hline & Coef & Std. Error & t-Statistic & Prob. \\
\hline $\begin{array}{l}\text { Constant } \\
\text { Inflation(-1) } \\
\text { Inflation(1) } \\
\text { Output Gap(-9) } \\
\text { Exchange Rate Dep(-1) } \\
\text { M1 Growth(-2)<=9.84\% } \\
9.84 \%<\text { M1 Growth(-2)<= 17.13\% } \\
17.13 \%<\text { M1 Growth(-2) } \\
\text { Dummy Crisis } \\
\text { Dummy Fuel } \\
\text { Dummy Fitri }\end{array}$ & $\begin{array}{l}-0.571 \\
0.689 \\
0.248 \\
0.052 \\
-0.045 \\
0.127 \\
0.057 \\
0.038 \\
1.219 \\
2.835 \\
0.543\end{array}$ & $\begin{array}{l}0.190 \\
0.0371 \\
0.052 \\
0.021 \\
0.009 \\
0.035 \\
0.018 \\
0.009 \\
0.508 \\
0.643 \\
0.206\end{array}$ & $\begin{array}{l}-3.000 \\
8.537 \\
4.751 \\
2.447 \\
-5.302 \\
3.502 \\
3.079 \\
3.977 \\
2.400 \\
4.406 \\
2.639\end{array}$ & $\begin{array}{l}0.003 \\
0.000 \\
0.000 \\
0.015 \\
0.000 \\
0.001 \\
0.002 \\
0.000 \\
0.017 \\
0.000 \\
0.009\end{array}$ \\
\hline $\begin{array}{l}\text { Adjusted R-squared } \\
\text { S.E. of regression } \\
\text { SSR }\end{array}$ & $\begin{array}{c}0.992 \\
1.047 \\
358.479\end{array}$ & & & \\
\hline
\end{tabular}

\begin{tabular}{|c|c|c|c|c|}
\hline & Coef & Std. Error & t-Statistic & Prob. \\
\hline $\begin{array}{l}\text { Constant } \\
\text { Inflation(-1) } \\
\text { Inflation(1) } \\
\text { Output Gap(-9) } \\
\text { Exchange Rate Dep(-1) } \\
\text { M1 Growth(-2) }<=4.93 \% \\
4.93 \%<\text { M1 Growth }(-2)<=7.08 \% \\
7.08 \%<M 1 \text { Growth(-2)<= }<.84 \% \\
9.84 \%<M 1 \text { Growth(-2) } \\
\text { Dummy Crisis } \\
\text { Dummy Fuel } \\
\text { Dummy Fitri }\end{array}$ & $\begin{array}{l}-0.387 \\
0.684 \\
0.256 \\
0.049 \\
-0.045 \\
0.085 \\
0.169 \\
0.085 \\
0.031 \\
1.116 \\
2.926 \\
0.600\end{array}$ & $\begin{array}{l}0.152 \\
0.037 \\
0.052 \\
0.021 \\
0.009 \\
0.077 \\
0.055 \\
0.030 \\
0.008 \\
0.498 \\
0.639 \\
0.203\end{array}$ & $\begin{array}{l}-2.549 \\
18.475 \\
4.972 \\
2.317 \\
-5.186 \\
1.097 \\
3.094 \\
2.848 \\
3.900 \\
2.242 \\
4.576 \\
2.963\end{array}$ & $\begin{array}{l}0.011 \\
0.000 \\
0.000 \\
0.021 \\
0.000 \\
0.273 \\
0.002 \\
0.005 \\
0.000 \\
0.026 \\
0.000 \\
0.003\end{array}$ \\
\hline $\begin{array}{l}\text { Adjusted R-squared } \\
\text { S.E. of regression } \\
\text { SSR }\end{array}$ & $\begin{array}{c}0.992 \\
1.034 \\
348.456\end{array}$ & & & \\
\hline
\end{tabular}

